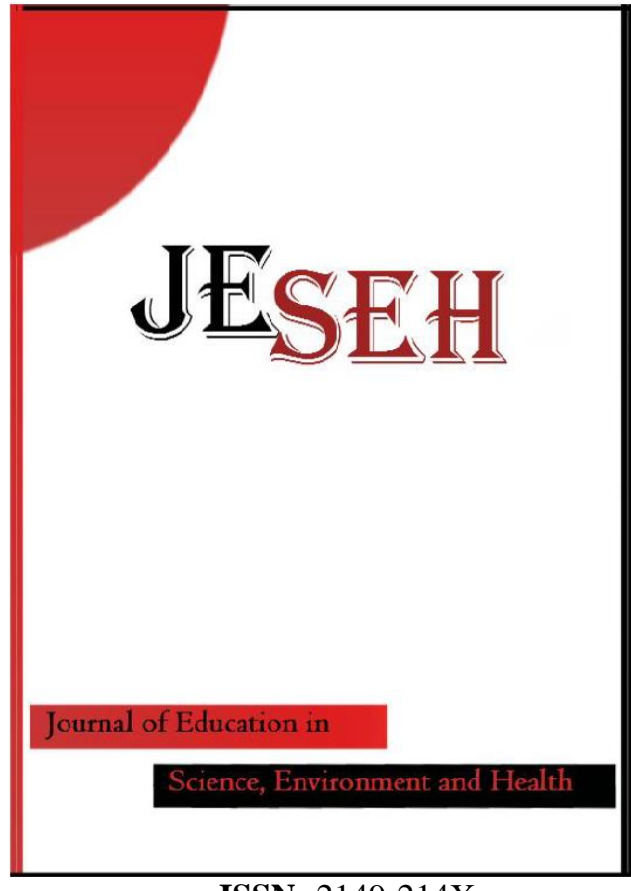

ISSN: $2149-214 \mathrm{X}$

\section{Journal of Education in Science, Environment and Health}

www.jeseh.net

The Effect of Technology-Supported Inquiry-Based Learning in Science Education: Action Research

Zeynep Koyunlu Unlu ${ }^{1}$, Ilbilge Dokme ${ }^{2}$

${ }^{1}$ Yozgat Bozok University

${ }^{2}$ Gazi University

To cite this article:

Koyunlu Unlu, Z. \& Dokme, I. (2020). The effect of technology-supported inquiry-based learning in science education: Action research. Journal of Education in Science, Environment and Health (JESEH), 6(2), 120-133. DOI:10.21891/jeseh.632375

This article may be used for research, teaching, and private study purposes.

Any substantial or systematic reproduction, redistribution, reselling, loan, sub-licensing, systematic supply, or distribution in any form to anyone is expressly forbidden.

Authors alone are responsible for the contents of their articles. The journal owns the copyright of the articles.

The publisher shall not be liable for any loss, actions, claims, proceedings, demand, or costs or damages whatsoever or howsoever caused arising directly or indirectly in connection with or arising out of the use of the research material. 


\title{
The Effect of Technology-Supported Inquiry-Based Learning in Science Education: Action Research
}

\author{
Zeynep Koyunlu Unlu, Ilbilge Dokme
}

\begin{tabular}{|c|c|}
\hline Article Info & Abstract \\
\hline Article History & $\begin{array}{l}\text { The general aim of this action research was to offer ways of making science and } \\
\text { technology education more effective and solving problems in the related field. }\end{array}$ \\
\hline $\begin{array}{l}\text { Received: } \\
\text { 12 July } 2019\end{array}$ & $\begin{array}{l}\text { The specific purpose was to determine how inquiry-based learning supported by } \\
\text { instructional technologies improves students' achievement and develops their }\end{array}$ \\
\hline $\begin{array}{l}\text { Accepted: } \\
15 \text { January } 2020\end{array}$ & $\begin{array}{l}\text { scientific inquiry skills. Taking into consideration the literature and the interest } \\
\text { areas of the researchers, the inquiry-based 5E instructional model was embedded } \\
\text { in a new framework of 4W questions ("What will I learn?", "Why will I learn?", }\end{array}$ \\
\hline Keywords & 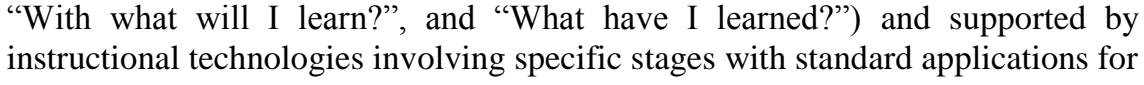 \\
\hline Action research & solving problems. The implementation was carried out at the seventh-grade level \\
\hline $\begin{array}{l}\text { Science education } \\
\text { Technology-sunnorted }\end{array}$ & in a Turkish middle school in a semester. The participants were a researcher- \\
\hline $\begin{array}{l}\text { Technology-supported } \\
\text { inquiry-based learning }\end{array}$ & $\begin{array}{l}\text { teacher and six students (two girls, four boys). According to the results, the } \\
\text { students' science achievement and scientific process skills developed. This }\end{array}$ \\
\hline & $\begin{array}{l}\text { implementation effectively addressed students' affective learning areas, such as } \\
\text { their attitudes, motivation, sense of responsibility, and values in relation to the } \\
\text { learning environment. It is hoped that the results of this research will offer } \\
\text { insights for researchers and practitioners. }\end{array}$ \\
\hline
\end{tabular}

\section{Introduction}

With the advancement of science and technology, teacher-centered classical approach used in educational environments has been replaced by active learning approach. One of the active learning approaches is inquirybased learning. Inquiry-based learning is based on the pragmatism philosophy developed by Charles Sanders Pierce, William James, and John Dewey in the early 20th century (Bakır, 2006). This learning approach, which has been included in science teaching programs for a long time (American National Research Commission [NRC], 1996) and maintains its popularity (Shahali, Halim, Treagust, Won, \& Chandrasegaran, 2017), is defined by NRC as follows:

\begin{abstract}
Inquiry is a multifaceted activity that involves making observations; posing questions; examining books and other sources of information to see what is already known; planning investigations; reviewing what is already known in light of experimental evidence; using tools to gather, analyze, and interpret data; proposing answers, explanations and predictions; and communicating the results. Inquiry requires identification of assumptions, use of critical and logical thinking, and consideration of alternative explanations (NRC, 2000, p. 23).
\end{abstract}

Inquiry-based learning categorized as open-ended, guided, compound, and structured (Lustick, 2009; MartinHansen, 2002). Different types of inquiry-based learning are used in accordance with the characteristics and needs of the topics to be covered in science classes (Sadeh \& Zion, 2012). The 5E Model, consisting of engagement, exploration, explanation, elaboration, and evaluation, is one of the ways of organizing inquirybased science courses using inquiry-related skills (Melber, 2004; Kim, 2011). In this model, each step is built on the previous one (Warner \& Myers, 2011). The details of the implementation of these steps are given below (Bybee, 2002):

(1) Engagement: The teacher tries to identify students' existing knowledge and misconceptions about the target subject. S/he introduces the subject in a way that draws students' attention and presents direct questions about the subject to be covered. The aim here is not to find the right answer but to engage students' minds. The question, "How can I explain this?", forms the basis of this stage.

(2) Exploration: Students conduct experiments either individually or through questions that engage their minds or utilize a source (e.g., books and computers). In this way, students have the opportunity to 
share their ideas with others. As a result of the implemented activities, students may become aware of their deficiencies related to their pre-existing conceptualizations. Misconceptions can be remedied at this stage. Thus, at the basis of this stage is the question, "How can misconceptions be eliminated?".

(3) Explanation: Based on their experience, students explain their scientific terms and concepts in formal language. In cases where students think they are inadequate, the teacher can provide explanations at the basic knowledge level. The basis of this stage is how to make scientific explanations.

(4) Elaboration: Students apply the knowledge and skills they have acquired to new situations. "How to apply what has been learned to different situations?" is the fundamental question underlying this stage.

(5) Evaluation: A short assessment is undertaken to reveal what students have learned. Students are encouraged to use the knowledge and skills they have acquired in future activities. The question, "How do students apply their scientific conceptualizations and skills?", forms the basis of this stage.

The skills required for inquiry-based learning are called science process skills (SPSs). These skills appear not only in science but also in everyday life (Tan \& Temiz, 2003). SPSs are defined as skills that facilitate students' learning, provide them with the ability to research, allow them to be active in the learning environment and develop a sense of taking responsibility in their learning, and increase the retention of learned information. These skills are examined in the following three groups: Basic skills are related to observation, measurement, classification, data recording, and establishing numerical and spatial relationships. They provide the basis for the development of higher-level competencies. Causal skills concern prediction, identification of variables, and making inferences. These skills include the creation of testable hypotheses. Experimental skills require a high level of thinking, such as building hypotheses, constructing models, experimenting, changing and controlling variables, and decision making. These skills are a continuation of what has already been gained (Ayas, Çepni, Akdeniz, Özmen, Yiğit, \& Ayvac1, 2005).

Although inquiry-based learning contributes to students' cognitive and affective traits, such as their achievement and inquiry skills and attitudes (Acar Sesen \& Tarhan, 2013; Cabe Trundle, Atwood, Christopher, \& Sackes, 2010; Furtak, Seidel, Iverson, \& Briggs, 2012; Hofstein, Navon, Kipnis, \& Mamlok-Naaman, 2005; Lazonder \& Harmsen, 2016), there are some difficulties in the implementation of this method, which results from lack of time, teacher beliefs, availability of materials and motivation, pedagogical deficiencies, administrative problems, overcrowded classes, and security problems (Cheung, 2011; Edelson, Gordin, \& Pea, 1999). In addition, teachers face the challenge of needing to develop more skills to effectively implement inquiry-based learning. Since teachers are involved in students' decision-making, inquiries, research and communication with their peers, they should have knowledge of the field and the ability to think quickly (Jarrett, 1997, p. 25). A recent study revealed that teacher candidates had difficulty in designing and implementing an inquiry-based learning process (Talanquer, Tomanek, \& Novodvorsky, 2013). Similarly, other researchers reported that many inquiry-based activities undertaken in schools were not sufficient to capture the distinguishing features of authentic scientific research (Chinn \& Hmelo-Silver, 2002), and scientific research widely conducted in schools differed from real scientific research in terms of qualitative aspects (cognitive processes and the underlying philosophy of knowledge) (Chin \& Malhotra, 2000). Some researchers (Lederman et al., 2014; Schwartz, Lederman \& Lederman, 2008) criticized the idea that merely performing inquiry-based activities would improve students' understanding of how to conduct scientific research. In addition, it was found that providing students with an authentic research environment by engaging them in the process produced more effective results than a teacher-centered approach in which students were taught what research was and how it was undertaken (Lustick, 2009; Rendall, 1996).

Students need to possess certain knowledge and skills in order to understand the purpose of activities carried out in the inquiry-based learning process, obtain data, and analyze and interpret the collected data. Having an insufficient level of such knowledge and skills prevents meaningful learning (Edelson et al., 1999). At this point, technology can be incorporated into the learning process. In science courses at middle school level, digital images and videos, computer simulations, deepening software, online data acquisition for scientific analysis, web-based inquiry projects, and virtual science classes can be used (Bell, Gess-Newsome, \& Luft, 2008). Beishuizen, Wilhelm, and Schimmel (2004) suggested that research skills students should have for effective learning; e.g., monitoring two or more variables when constructing a hypothesis, were difficult to understand for sixth-graders aged nine to ten years, and the development of these necessary skills could be supported using computer simulations. Similarly, de Jong (2006) stated that computer simulations could help improve skills utilized in the inquiry cycle, related to hypothesizing, determining variables and the relationships between them, making inferences, and interpretation. In cases where the classroom environment is not appropriate for data collection (Lee \& Songer, 2003; Uçar \& Trundle, 2011), the use of technology in the learning process promotes the visualizing of the lesson, facilitates the work of the teacher, and widens the perspective of students (Bozdoğan, 2011). Technology incorporates students into the learning process by allowing them to establish 
strong links between independent, cumulative information held in their mind and transfer this knowledge to new situations (Novak \& Krajick, 2006).

Although technology-supported inquiry-based learning is considered to be more effective (Edelson et al., 1999; Uçar \& Trundle, 2011; van Joolingen, de Jong, \& Dimitrakopoulout, 2006), it is difficult to adopt this method, especially in rural areas due to the digital divide defined as regional inequality in the availability of information and communication technologies (Gündüz, 2010; Koyunlu Ünlü, Dökme, \& Sarıkaya, 2014; Turkish Telecommunications Authority [TTA], 2002; Yang et al., 2013). Furthermore, financial hardships experienced especially in rural areas make it difficult for students to visit museums and science centers that offer authentic learning. Providing opportunities for these students to develop their scientific research skills and integrating scientific research into technology constitute the basis of the equality principle in education. Engaging in simple activities, such as showing an advertisement, a short video or pictures, can also help create an authentic learning environment.

The current research aimed to investigate the effects of the proposed technology-supported inquiry-based learning program on the science and technology course achievements and scientific research skills of middle school students in a rural area. It also aimed to reveal the changes in the students' views and perceptions concerning inquiry and technology following the implementation of this program. This study is important in terms of filling a gap in the literature related to research in rural areas in Turkey through its objective to provide a new perspective for in-service and pre-service teachers in similar contexts. Thus, the main research question was defined as, "What are the effects of the proposed technology-supported inquiry-based learning application on the science and technology course achievements and scientific research skills of middle school students in the rural setting?" Accordingly, the sub-problems of the research were defined as follows:

(1) How did this application affect the students' achievements in the science and technology courses?

(2) How did the students' scientific process skills change after the implementation?

(3) What did the participants (teacher and students) think about the implementation?

\section{Method}

\section{Research Model}

This study was designed as action research to improve the quality of the learning process. Action research can be defined as "any systematic inquiry conducted by teacher researchers, principals, school counselors, or other stakeholders in the teaching-learning environment, to gather information about ways that their particular schools operate, how they teach, and how well their students learn.” (Mills, 2007, p. 5). In action research, both qualitative and quantitative data collection techniques can be used (Bogdan \& Biklen, 1982). The stages used in the current action research used were identified from the relevant literature and are presented in Figure 1.

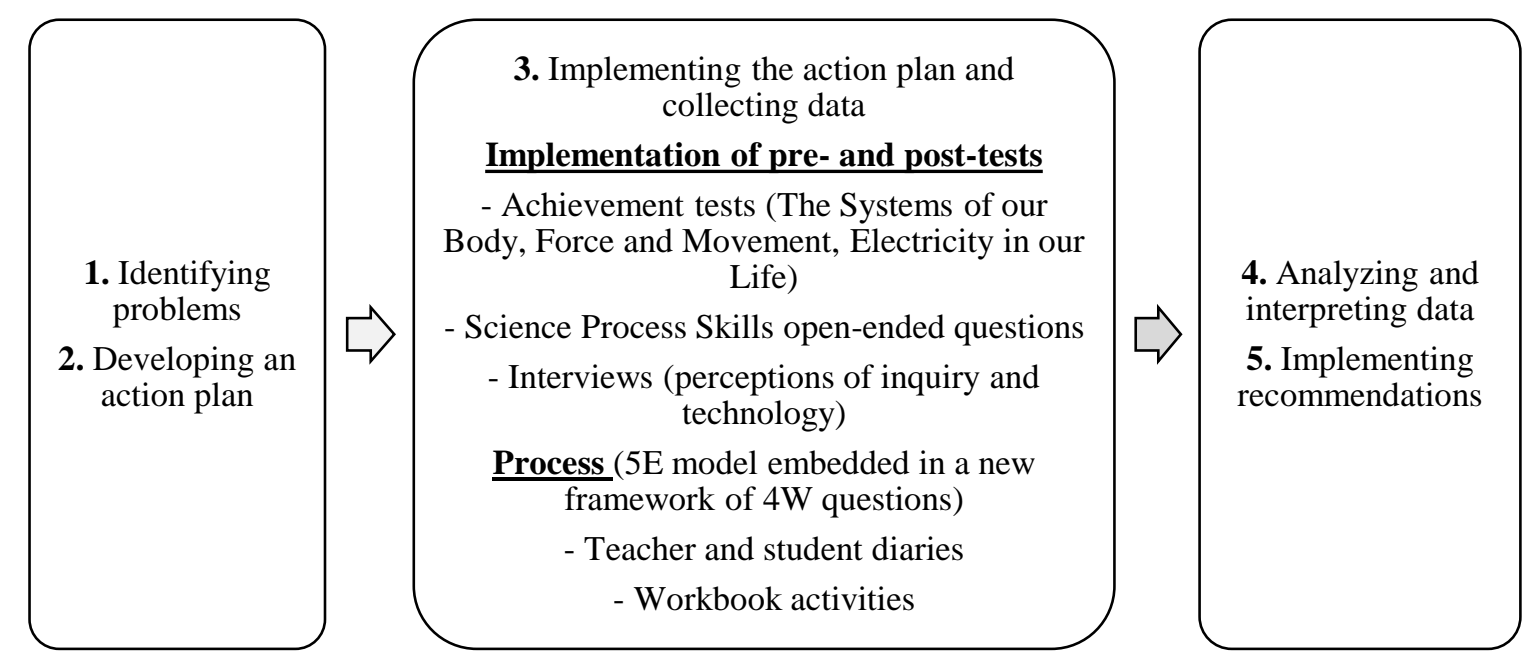

Figure 1. Stages of the current research 
The stages presented in Figure 1 were specifically developed by the researchers of the current study. The research began with a focus on solving existing problems. The teacher, who had the role of both a researcher and a practitioner, had worked for six years in the school chosen for the research. She had taught the science and technology course for a year in the selected class according to the teacher's guide to teaching the sixth-grade lesson plans within the framework of the curriculum program developed by the Ministry of National Education (MoNE) and the Board of Education and Discipline. In the book, each unit is dedicated to a specific topic organized according to the 5E Model based on the constructivist approach. There are also suggested activities in the book. Based on her observation and experience, the teacher identified that she encountered the following problems in teaching in relation to this model:

(a) Students' awareness of what, why and with what to learn included in the 5E model proposed in the program is not at the desired level.

(b) Students are less motivated when only science and technology textbooks are used during course work.

(c) Students are not aware of the importance of conducting scientific research in science courses; the majority of students consider that research is merely about printing something or finding a picture somewhere related to the topic and gluing it on a piece of paper.

(d) Students are not familiar with the use of technological equipment due to the location of the school and their families having a low socioeconomic status; although they are very willing to use computers to access information when doing homework, they do not have sufficient resources to achieve this.

Table 1. Template lesson plan

What will I learn?

Engagement: 1. The name of the unit and subject and gains are presented to the students. Preliminary knowledge of the students is determined and any deficiencies are eliminated.

Why will I learn?

2. Students are asked why they will learn this subject. Examples are given from daily life related to the subject. Where appropriate, examples are brought to the class. Students are encouraged to engage in practice on these examples, create problems in their minds and think about these problems. For items that cannot be brought to the class, photos can be shown with a PowerPoint presentation to create a discussion environment for students. In this section, the teacher draws attention to the subject and motivates students to learn about the new subject by asking questions related to daily life that will increase their interest.

3. Videos from daily life related to the subject are shown to generate the problem in students' minds. The identified problems are discussed through these videos.

\section{With what will I learn?}

Exploration: 4. The activities included in the science textbooks and organized by the researchers in accordance with the steps of scientific research specified by the National Science Teaching Association (NSTA) are undertaken by students.

5. Videos, simulations and/or animations related to each activity are shown to students.

Explanation: 6. Students are encouraged to provide written/verbal explanations based on their experiences in the exploration stage.

Elaboration: 7. Students are encouraged to engage in activities to deepen their knowledge of the subjects they have learned. These activities are supported by visual materials, such as computer simulations, animations, photographs, films, and documentaries that are available to the researcher.

What have I learned?

Evaluation: 8. The changes in the knowledge of students throughout the implementation process are evaluated.

Table 1 shows the template of the lesson plan used in this research. In the development of an action plan, the problems identified by the researcher, her interest areas, and the related literature were taken into consideration. In light of this information, the following actions were taken to resolve the identified problems:

(a) The inquiry-based instructional 5E Model was reframed using the 4W questions of "What will I learn?", "Why will I learn?", "With what will I learn?", and "What have I learned?" and supported by instructional technologies (videos, animations, and simulations); then, the course plans were revised according to the updated model. This aimed to increase the students' awareness and motivation about what, why and how they would learn, reduce course work by relying solely on textbooks, and integrate technology with science.

(b) Tests were prepared to evaluate student achievements.

(c) Scientific research activities were performed to monitor the changes in the scientific research skills of the students. 
(d) The teachers and the students recorded their thoughts and feelings about the implementation in a diary in the last 10 minutes of each class hour.

The data were collected during one academic term. Fifty-six hours of this period were devoted to the application of inquiry-based learning supported by instructional technologies, six course hours were allocated to achievement tests and two course hours to the administration of open-ended questions for SPS. Each lesson hour was 40 minutes.

\section{Data Collection Tools}

\section{Quantitative Data Collection Tools}

In this research, in order to evaluate student achievements, multiple-choice (four options) achievements tests were prepared for the following course units: the systems of our body, force and movement, and electricity in our life. The achievement tests developed were administered to the students at the beginning and end of each unit. In the development of these achievement tests, the following steps were undertaken (At1lgan, Kan, \& Doğan, 2013): (1) Identifying the purpose of use for the test scores, (2) determining gains, creating the table of specifications, and preparing draft items, (3) reviewing the draft items, (4) preparing the draft test form, (5) implementing the draft test, and (6) selecting items for the final test based on the results of item analysis on the draft version. The test forms prepared for the systems of our body" (40 questions), force and movement (38 questions), and electricity in our life (37 questions) were administered to 187, 202 and 212 seventh-grade students, respectively and had measurement reliability (KR-20) values of $0.88,0.87$, and 0.86 , respectively. During the development of the tests, $27 \%$ of the number of students who answered the test was calculated. The upper and lower groups were determined. The item difficulty index (p) and item discrimination index (r) of each item were calculated from the scores of the upper and lower groups. After the calculations, items with a substance discrimination index of 0.30 and above and a substance difficulty index between 0.20 and 0.81 were taken to the final test.

The SPS self-evaluation form consisting of six open-ended questions prepared by the authors to determine the students' SPS was applied to the participants before and after the application. These questions measured the students' ability to record data, process and model data, interpreting data and making inferences, identify variables, and construct hypotheses. In the process of developing open-ended questions related to SPS, the science subjects from the previous year and expert opinions (Ph.D. in science education) were taken into consideration. The experts did not change the number of questions and the skills measured by the questions. They only offered suggestions in terms of narration. The pilot implementation of the questions was conducted on a similar group. The students' responses to these questions were digitized by scoring. Through these questions, the changes in the students' ability to record data, process and model data, interpret data and make inferences, identify variables, and hypothesize were monitored.

\section{Qualitative Data Collection Tools}

Qualitative data were collected through the following documents: teacher and student diaries and the SPS selfevaluation form related to scientific research activities. The diaries kept by the teacher and the students aimed to reveal their thoughts on the implementation of technology-supported inquiry-based learning. The last ten minutes of each class was dedicated to this activity. During the implementation process, a total of seven, ten and 13 scientific inquiry activities were carried out in relation to the systems of our body, force and movement and electricity in our life units, respectively, and at the end of each activity, the students were asked to mark the SPS they used during each activity in the SPS self-evaluation form.

\section{Data Analysis}

As it was open-ended, the data obtained from the SPS test was first analyzed by content analysis and then digitized and converted into quantitative data. The data obtained from the achievement tests and SPS openended questions were analyzed at the significance level of $\alpha=0.05$ using the Statistical Package for the Social Sciences (SPSS) v. 15. Since there were six participant students, as a non-parametric statistical analysis, the Wilcoxon signed-rank test values were calculated for the comparison of data (Wilcoxon, 1945). The responses to the open-ended SPS questions and the data from the teacher and student diaries were examined using content 
analysis. During this process, the logs were first dumped, read over and over again, and first codes and then categories were formed. The data obtained from the SPS self-assessment forms were digitized, and the average values of the skills used by all students in each scientific research activity were recorded.

\section{Ethical Issues}

Since the selected school was a public school operating under MoNE, the "Directive for the Approval and Implementation of Research and Research Support in Schools and Institutions Affiliated to the Ministry of National Education" (MoNE, 2006) was followed. Before the implementation of the program, official permission was obtained from MoNE, and the parents of the students were informed about the aim, duration and content of the research and signed a written informed consent form stating that they agreed to their children's participation in research. Similarly, the students provided their written consent as voluntary participants.

\section{Validity and Reliability of the Research}

The researcher had been engaged in this research field for seven years. The implementation took 4.5 months One of the strengths of this research was that the researcher conducted the study in her own school and class with her own students. Multiple data collection tools were used to provide data diversity and reliability in the study (Johnson, 2014; Patton, 2002). During the development of lesson plans and data collection tools, opinion was obtained from different experts with a PhD degree and experience in teaching. Two lecturers and two teachers were consulted at all stages of the implementation in order to minimize the bias of the researcher. Two researchers (authors) individually performed coding and met at specific time intervals to discuss and reach an agreement on the codes, categorizations, and themes.

\section{Results}

\section{Effect of the Implementation on Student Achievement}

The Wilcoxon signed-rank test was conducted to determine whether there was a change in the students' average scores in the pre- and post-tests related to their achievement in the systems of our body, force and movement, and electricity in our life course units. The results of these tests are presented in Table 2.

Table 2. Results of the Wilcoxon signed-rank test on the students' pre- and post-implementation achievement

\begin{tabular}{|c|c|c|c|c|c|c|}
\hline \multicolumn{7}{|c|}{ scores } \\
\hline $\begin{array}{l}\text { Achievement } \\
\text { tests }\end{array}$ & $\begin{array}{l}\text { Post-test- } \\
\text { pre-test }\end{array}$ & Mean rank & Rank sum & $\mathrm{z}$ & $\mathrm{p}$ & $\mathrm{r}$ \\
\hline \multirow[b]{2}{*}{$\begin{array}{l}\text { The Systems } \\
\text { of Our Body }\end{array}$} & Negative rank & .00 & .00 & 2.2 & .028 & 0.63 \\
\hline & $\begin{array}{c}\text { Positive rank } \\
\text { Tied }\end{array}$ & 3.5 & 21 & & & \\
\hline \multirow{2}{*}{$\begin{array}{l}\text { Force and } \\
\text { Movement }\end{array}$} & Negative rank & .00 & .00 & 2.02 & .04 & 0.58 \\
\hline & $\begin{array}{c}\text { Positive rank } \\
\text { Tied }\end{array}$ & 3 & 15 & & & \\
\hline \multirow{2}{*}{$\begin{array}{l}\text { Electricity in } \\
\text { Our Life }\end{array}$} & Negative rank & .00 & .00 & 2.2 & .02 & 0.58 \\
\hline & $\begin{array}{c}\text { Positive rank } \\
\text { Tied }\end{array}$ & 3.5 & 21 & & & \\
\hline
\end{tabular}

As shown in Table 2, there was a statistically significant difference between the students' pre-test and post-test scores in favor of the latter with the following values: $\mathrm{z}=2.2, \mathrm{p}<.05$, and $\mathrm{r}=0.58$ for the systems of our body; $\mathrm{z}=2.02, \mathrm{p}<.05$, and $\mathrm{r}=0.58$ for force and movement; and $\mathrm{z}=2.2, \mathrm{p}<.05$, and $\mathrm{r}=0.58$ for electricity in our life. Thus, the implementation improved the participants' academic achievement.

\section{Effect of the Implementation on the Participants' Views on Inquiry}

The second sub-problem of the study aimed to reveal the effect of implementing technology-supported inquirybased learning on the students' SPS. For this purpose, the SPS open-ended questions were administered to the 
students as pre- and post-tests, and the scores obtained were subjected to Wilcoxon signed-ranks test in SPSS software (Table 3).

Table 3. Results of the Wilcoxon signed-rank test on the students' pre- and post-test scores in the SPS evaluation form

\begin{tabular}{|c|c|c|c|c|c|c|}
\hline SPS & $\begin{array}{l}\text { Post-test- } \\
\text { Pre-test }\end{array}$ & Mean rank & Rank sum & $\mathrm{z}$ & $\mathrm{p}$ & $\mathrm{r}$ \\
\hline \multirow[b]{2}{*}{ Data recording } & Negative rank & .00 & .00 & 2.07 & 0.3 & 0.6 \\
\hline & $\begin{array}{c}\text { Positive rank } \\
\text { Tied }\end{array}$ & 3 & 15 & & & \\
\hline \multirow{2}{*}{$\begin{array}{l}\text { Data processing } \\
\text { and modelling }\end{array}$} & Negative rank & .00 & .00 & 3.17 & .00 & 0.91 \\
\hline & $\begin{array}{c}\text { Positive rank } \\
\text { Tied } \\
\end{array}$ & 6.5 & 78 & & & \\
\hline \multirow{2}{*}{$\begin{array}{l}\text { Interpreting data } \\
\text { and making } \\
\text { inferences }\end{array}$} & Negative rank & .00 & .00 & 2.42 & .01 & 0.7 \\
\hline & $\begin{array}{c}\text { Positive rank } \\
\text { Tied }\end{array}$ & 4 & 28 & & & \\
\hline \multirow[b]{2}{*}{$\begin{array}{l}\text { Identifying } \\
\text { variables }\end{array}$} & Negative rank & .00 & .00 & 2.87 & .00 & 0.83 \\
\hline & $\begin{array}{c}\text { Positive rank } \\
\text { Tied }\end{array}$ & 5.5 & 55 & & & \\
\hline \multirow[b]{2}{*}{$\begin{array}{l}\text { Constructing } \\
\text { hypotheses }\end{array}$} & Negative rank & .00 & .00 & 2.58 & .01 & 0.74 \\
\hline & $\begin{array}{c}\text { Positive rank } \\
\text { Tied }\end{array}$ & 4.5 & 36 & & & \\
\hline
\end{tabular}

There was a significant difference between the students' pre-test and post-test scores obtained from the SPS self-evaluation form, and this was in favor of the post-test scores. The values calculated for each investigated SPS were as follows: $\mathrm{z}=2.07, \mathrm{p}<.05, \mathrm{r}=0.6$ for data recording, $\mathrm{z}=3.17, \mathrm{p}<.05, \mathrm{r}=0.91$ for data processing and modeling, $\mathrm{z}=2.42, \mathrm{p}<.05, \mathrm{r}=0.7$ for interpreting data and making inferences, $\mathrm{z}=2.87, \mathrm{p}<.05, \mathrm{r}=0.83$ for identifying variables, and $\mathrm{z}=2.58, \mathrm{p}<.05, \mathrm{r}=0.74$ for constructing hypotheses. Thus, the implementation improved the students' SPSs. Figure 2 shows the students' use of SPSs in scientific research activities by unit. This finding was obtained from the self-assessment form completed by the students after performing the activities.

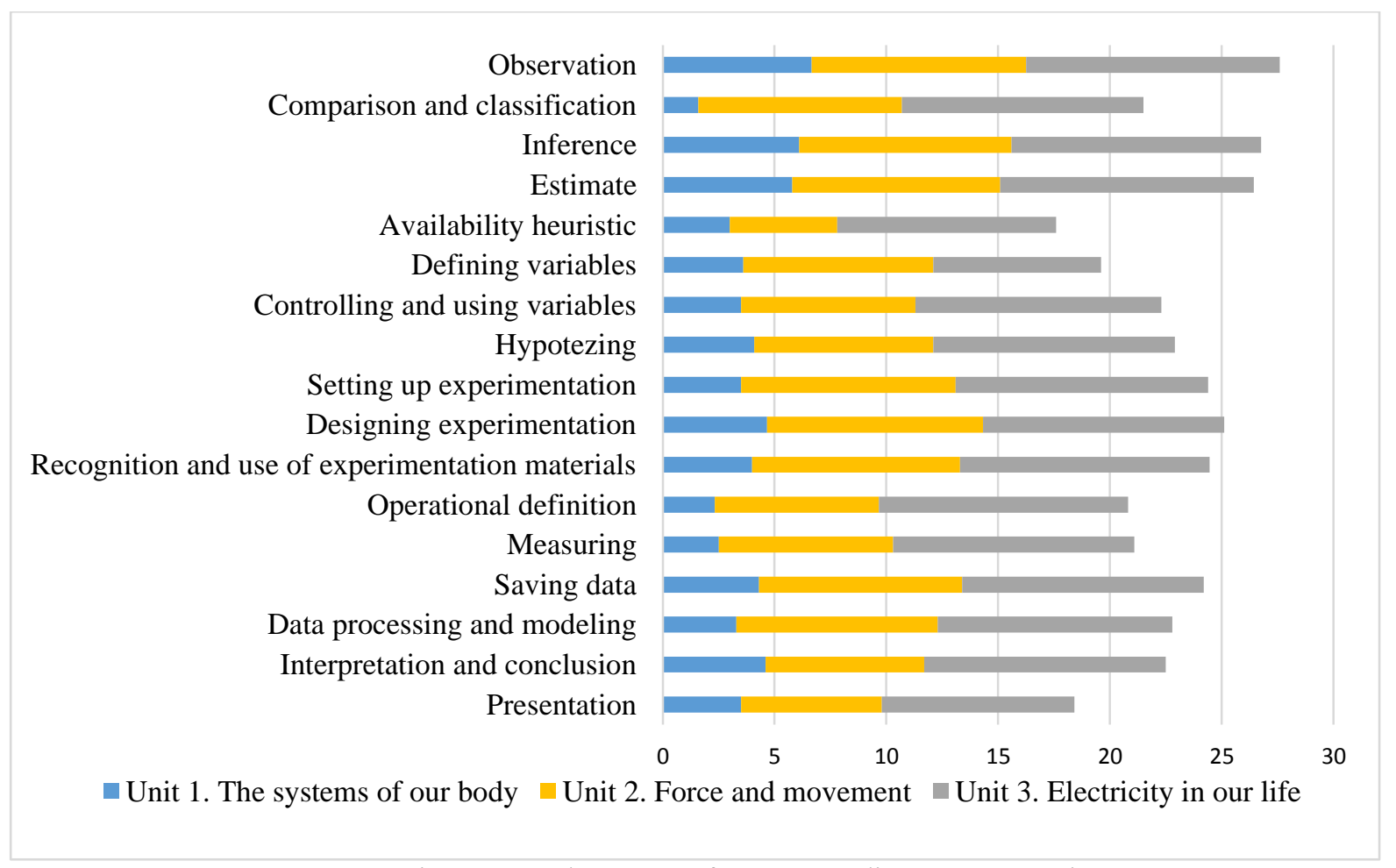

Figure 2. Students' use of SPSs according to course units 
As shown in Figure 2, the students' use of SPSs in the activities of the systems of our body, force and movement, and electricity in our life units increased throughout the implementation.

\section{Participants' Views on the Implementation}

The third sub-problem of the study aimed to reveal the participants' views concerning the implementation of technology-supported inquiry-based learning. The teacher's views on the implementation were categorized under the headings of scientific research/activities, technology, workbook activities, and awareness of SPSs. The teacher (first author) stated that the students were willing to conduct scientific research activities, but the available course hours were not sufficient. In addition, she commented that technology used in the classroom increased students' interest in the lessons.

There is limited time for practice in science lessons...The students liked the technology used. I think the final animation is more effective and enjoyable than the ones written in Power Point.

The teacher also reported that the students enjoyed watching animations, which provided more permanent learning, and using videos in teaching increased the students' motivation and quality of learning.

The course went well. Students watched videos very carefully.

She considered that the students had difficulty carrying out the activities in the workbook, which she attributed to their lack of understanding of what they read.

There is difficulty in reading and understanding activities. Even at guided events, they ask, How do we do that?

Table 4. Students' views on the learning environment

\begin{tabular}{|c|c|c|c|}
\hline Category & Sub-category & Code & Frequency \\
\hline \multirow{20}{*}{ Attitudes } & \multirow{8}{*}{$\begin{array}{l}\text { General attitude toward the teaching of } \\
\text { the course }\end{array}$} & Entertaining & 29 \\
\hline & & Enjoyable & 7 \\
\hline & & Understandable & 2 \\
\hline & & Desirable & 33 \\
\hline & & Good & 30 \\
\hline & & Excellent & 2 \\
\hline & & Exciting & 1 \\
\hline & & Moderate & 1 \\
\hline & \multirow{7}{*}{$\begin{array}{l}\text { Attitude toward the scientific inquiry } \\
\text { activities undertaken during the course }\end{array}$} & Reinforces learning & 4 \\
\hline & & Facilitates learning by doing & 1 \\
\hline & & Makes learning interesting & 2 \\
\hline & & Makes learning fun & 2 \\
\hline & & Satisfying & 1 \\
\hline & & Nice to create a product & 1 \\
\hline & & Not fun & 1 \\
\hline & \multirow{5}{*}{$\begin{array}{l}\text { Attitude toward technology used in the } \\
\text { course }\end{array}$} & $\begin{array}{l}\text { Helps retention of learned } \\
\text { information }\end{array}$ & 1 \\
\hline & & Entertaining & 5 \\
\hline & & $\begin{array}{l}\text { Provides a better learning } \\
\text { environment }\end{array}$ & 3 \\
\hline & & Makes learning fun & 1 \\
\hline & & Facilitates learning & 2 \\
\hline Motivation & $\begin{array}{l}\text { Willingness to learn about science and } \\
\text { perform science-related activities }\end{array}$ & & 5 \\
\hline \multirow{2}{*}{ Values } & $\begin{array}{l}\text { Importance attached to the subject } \\
\text { taught }\end{array}$ & & 7 \\
\hline & $\begin{array}{l}\text { Importance attached to the course in } \\
\text { general }\end{array}$ & & 6 \\
\hline Responsibility & & & 6 \\
\hline
\end{tabular}


At the same time, the teacher observed that the students easily conducted activities at the level of knowledge and understanding in the workbook, but it was difficult for them to perform those that required analysis-synthesis skills. She stated that during the implementation, the students understood the topics but needed extra time to successfully undertake the assessment activities in the workbook. The teacher also noted that although SPSs were included in the Secondary School Science Curriculum (MEB-TTKB, 2013), the students were initially not aware of these skills, but through conducting scientific research activities, they developed this awareness. As the implementation progressed, the teacher indicated that the students with moderate- and high-level achievements had better awareness of SPSs.

The students' views on the implementation were analyzed under the themes of the students' attitudes, motivation, values and sense of responsibility related to the science course concerning affective learning and comparison with the previous approach used in the teaching of the course. It was determined that the implementation of technology-supported inquiry-based learning helped the students develop positive attitudes toward the science course and enjoy learning science. Throughout the implementation process, the students were observed to be better motivated, more willing to learn the units, and more interested in the lessons. It was seen that supporting inquiry-based learning with technology appealed to the students' affective learning.

As shown in Table 4, the students generally described the implementation of technology-supported inquirybased learning as entertaining $(n=29)$, enjoyable $(n=7)$, understandable $(n=2)$, good $(30)$, excellent $(n=2)$, and moderate $(n=1)$, they mostly liked this implementation $(n=33)$, and the subjects covered were exciting $(n$ $=1)$. For example, a participant stated:

Today we learned the digestive system in science. We learned where it started, where it went through and where it ended. The course was very nice and I understood everything. I liked everything in class.

The students stated that the scientific inquiry activities carried out during the course provided the retention of information learned $(n=4)$ and encouraged learning by doing $(n=1)$. The students also considered that scientific research was interesting $(n=2)$, fun $(n=2)$ and satisfying $(n=1)$, and one student enjoyed creating a product. Only one student mentioned that scientific research was not fun $(n=1)$. A participant remarked:

We learned very important things by scientific inquiry activities, we understood better. I'm looking forward to the next science class.

The students described the technology used in the course as providing retention of learned information $(n=1)$ and better learning $(n=3)$, and making learning easier $(n=2)$, entertaining $(n=5)$, and fun $(n=1)$. A participant stated:

Technology is important not only for this course, but for all courses

and another participant commented:

Today we watched videos again. Videos make it easy for us to learn.

Some of the students also referred to responsibilities they undertook by commenting on the work they had to undertake in order to be successful in the course $(n=6)$.

\section{Discussion and Conclusion}

The implementation of technology-supported inquiry-based learning was found to improve the participants' academic achievement, which is consistent with previous studies (Bell, Maeng \& Binns, 2013; Bellflower, 2011; Cabe Trundle \& Hobson, 2011; Eslinger, White, Frederiksen, \& Brobst, 2008; Kim, 2011; Koyunlu Ünlü \& Dökme, 2011; Lee, Linn, Varma, \& Liu, 2010; Maeng, Mulvey, Smetana, \& Bell, 2013; Uçar \& Trundle, 2011). Bellflower (2011) reported that 21st century learning tools, such as online teachers, video games, YouTube, and virtual laboratories provided a greater positive contribution to student achievement and classroom performance compared to traditional teaching instruments. Kim and Hannafin (2011) argued that supporting scientific research with technology was an effective approach for problem solving. Some researchers also addressed the favorable effects of inquiry-based learning supported by software on concept teaching (Cabe Trundle \& Hobson, 2011; Uçar \& Trundle, 2011). In the current research, science was associated with daily life, and the proposed application was supported by technology, scientific research, and related activities. In addition, 
with the planning of lessons under $4 \mathrm{~W}$ headings, it was aimed that the students would learn by inquiring about science topics. This implementation increased student motivation, allowing them to learn by doing, and thus positively influencing their success. Many scientists investigating the relationship between motivation and success have developed various theories. For example, Keller, Wlodkowski, Herzberg, Maslow, Mayo, McClelland, McGregor, Likert, Luthans, and Vroom all developed theories that focused on the important effect of motivation on students' learning (Dede \& Yaman, 2008, p. 21). Over almost a century, many studies have been conducted on how inquiry-based learning with a constructivist approach increased students' success in science courses (Furtak, Seidel, Iverson, \& Briggs, 2012). The most important factor that increased success in these studies was encouraging students to learn by doing things themselves. Similarly, the part of "With what will I learn" encouraged students to learn by doing.

Some researchers argue that Turkey's low level of achievement in the TIMSS-R test is due to the lack of emphasis on the nature of science and scientific research in education (Bağc1 K1lıç, 2002). In the proposed implementation, the 5E Model was reframed under 4W headings and integrated into the lesson plans. Scientific research and activities were planned for the exploration and 'elaboration stages of the 5E Model. This allowed the students to learn how to perform scientific research and activities by inquiry and practice and become aware of their importance. According to the results obtained from this research and the literature, the students should be provided with the opportunity to personally undertake research in order for them to develop positive attitudes toward inquiry. The problems commonly encountered in primary education include teachers and students having sufficient knowledge concerning scientific research, the general belief that scientific research can only be learned by undertaking scientific research, and the teachers' not effectively applying scientific research in their class, not having a complete understanding of scientific research practices or attempting to perform scientific research in the class using traditional methods. For students to develop scientific perceptions, it is necessary to explore how they perceive scientific research and develop practices that will encourage them to learn more about scientific research (Lederman \& Lederman, 2005).

In the current study, the technology-supported inquiry-based learning program positively affected the students' SPSs. Through scientific research and other activities conducted during the application process, the students' skills related to observation, comparison, inference, identification of variables, hypothesizing, designing and setting up experiments, recording data, and processing data and modeling developed. It can be stated that this development in the SPSs of the students stemmed from the scientific research and other activities undertaken during the exploration and elaboration stages of the 5E Model embedded in 4W. Previous studies also showed that technology-based inquiry-based learning contributed to the development of SPSs (Eslinger et al., 2008; Lin, Hsu, \& Yeh, 2012; Trundle \& Hobson, 2011). In this regard, the results of the current research are consistent with the relevant literature.

Research undertaken in science education at the national level emphasizes that SPSs are not sufficiently known by teachers (Türkmen \& Kandemir, 2011) and teacher candidates (Ateş, 2005). These negativities can only be overcome if all scientific research and activities carried out are aimed at developing SPSs. Durmaz and Mutlu (2014) found that the science course designed with a focus on SPSs improved the seventh-grade students' related skills. The authors implemented the activities in the textbook with an SPS-centered approach and helped the students become aware of SPSs.

The teacher's views on the implementation were discussed under the headings of scientific research/activities, technology, workbook activities, and awareness of SPS. The teacher stated that the students were willing to perform scientific research activities, but the time allocated was not sufficient for such activities. The teacher also noted that the technology used in the course increased the students' interest toward the lesson. In addition, the teacher considered that the students enjoyed watching the animations, which provided a more permanent learning and using videos increased the motivation and learning quality of the students. According to the teacher, although SPSs were included in the Middle School Science Curriculum (MEB-TTKB, 2013), the students were not aware of these skills and conducting scientific research activities in the process helped them develop such awareness. The students' views on the implementation were addressed under the headings of their attitudes, motivation, values and sense of responsibility related to the science course concerning affective learning and comparison with the previous approach used in the teaching of the course. The technologysupported inquiry-based learning program led the students to develop positive attitudes toward the science course and enjoy the learning process. It was seen that the students had high motivation during the implementation process, they were eager to engage in the activities in the course, and they attached importance to the subjects covered and the overall course. 
In this study, it was also determined that implementation of technology-supported inquiry-based learning with instructional technologies appealed to the students' affective learning. The views of the participant teacher and students about this learning approach were in parallel to the related literature (Kim, 2011; Li, 2014; Maeng, 2017; Ochsner, 2010; Waight \& Abd-El-Khalick, 2007). In previous research in which a similar inquiry-based program based on technology use was undertaken, both the teacher described technology as a source of information and motivation, and the students similarly referred to technology as a source of information (Waight \& Abd-El-Khalick, 2007). In another study, Ochsner (2010) found that using instructional videos in the lesson motivated the students to learn. Again, in research using a guided scientific research method enriched with technology, the students considered that technology made science teaching attractive, provided access to more accurate and scientific information, visualized the course, and thus facilitated the understanding of the subjects (Kim, 2011). Li (2014) also reported that using technology in science and mathematics education motivated the students. Maeng (2017) concluded that the use of technology in the science course played a complementary role, which is consistent with the results of the current research.

\section{Limitations and Recommendations}

This study has many strengths, including the use of multiple data collection tools, the relatively long study duration, and the program being implemented by one of the researchers. However, the limitations of the study are also acknowledged. For example, the achievements, skills and views of the students measured in the study were limited to the developed data collection tools. Similarly, the technology used was limited to the teacher's technological knowledge and skills, as well as the availability of technological tools. This research should be interpreted by the reader within the framework of these limitations.

Teachers use specific techniques in their class to provide better education. In order to systematize these implementations, teachers can be assigned the researcher role in action research to be conducted in the field of education to allow them to conduct research and be engaged in this process. Furthermore, in future studies, different dimensions of technology-supported inquiry-based research can be investigated. Teachers who want to avoid ordinary commonplace lessons can apply the action plan proposed and implemented in this research and develop similar plans for other course units.

\section{Acknowledgements or Notes}

This study includes a part of the first author's doctoral dissertation.

\section{References}

Acar Sesen, B., \& Tarhan, L. (2013). Inquiry-based laboratory activities in electrochemistry: high school students' achievements and attitudes. Research in Science Education 43, 413-435.

Ateş, S. (2004). The effects of inquiry-based instruction on the development of integrated science process skills in trainee primary school teachers with different piagetian developmental levels. Gazi Eğitim Fakültesi Dergisi, 24, 275-290.

Ayas, Atılgan, H., Kan, A., \& Doğan, N. (2013). Ĕgitimde ölçme ve değerlendirme [Measurement and evaluation in education]. Ankara: An1.

A. P., Çepni, S., Akdeniz, A. R., Özmen, H., Yiğit, N., \& Ayvacı, H. Ş. (2005). Kuramdan uygulamaya fen ve teknoloji ögretimi [Science and technology teaching from theory to practice]. Ankara: Pegem A.

Bağcı Kılıç, G. (2002). Üçüncü uluslararası matematik ve fen araştırması (TIMSS): Fen öğretimi, bilimsel araştırma ve bilimin doğası [Third international math and science research (TIMSS): Science teaching, scientific inquiry and the nature of science]. Ilkögretim Online, 2(1), $42-51$.

Bakır, K. (2006). Pragmatizm ve eğitime yansımaları [Pragmatism and its reflections on education]. KKEFD, $14,49-68$.

Bell, L., Gess-Newsome, J., \& Luft, C. (2008). Technology in the secondary science classroom. United States of America: NSTA Press.

Bell, R. L., Maeng, J. L., \& Binns, I. C. (2013). Learning in context: technology integration in a teacher preparation program informed by situated learning theory. Journal of Research in Science Teaching, 50, 348-379.

Bellflower, J. V. (2011). The effectiveness of traditional and 21st century teaching tools on students' science learning. Doctoral Dissertation, Walden University, Minneapolis. 
Beishuizen, J., Wilhelm, P., \& Schimmel, M. (2004). Computer-supported inquiry learning: effects of training and practice. Computers \& Education, 42(4), 389-402.

Bogdan, R. C., \& Biklen, S. K. (1982). Qualitative research for education: an introduction to theory and methods. Boston: Allyn and Bacon.

Bozdoğan, A. E. (2011). The effects of instruction with visual materials on the development of preservice elementary teachers' knowledge and attitude towards global warming. The Turkish Online Journal of Educational Technology, 10(2), 218-233.

Bybee, R. W. (2002). Learning science and the science of learning: science educators' essay collection. National Science Teachers Association.

Cabe Trundle, K. C., Atwood, R. K., Christopher, J. E., \& Sackes, M. (2010). The effect of guided inquiry based instruction on middle school students' understanding of lunar concepts. Research in Science Education, 40, 451-478.

Cabe Trundle, K. C., \& Hobson, S. (2011). To the moon and back. Science \& Children, (49)4, 51-55.

Cheung, D. (2011). Teacher beliefs about implementing guided-inquiry laboratory experiments for secondary school chemistry. Journal of Chemical Education, 88, 1462-1468.

Chinn, C. A., \& Hmelo-Silver, C. E. (2002). Authentic inquiry: introduction to the special section. Science Education, 86(2), 171-174.

Chinn, C. A., \& Malhotra, B. A. (2002). Epistemologically authentic reasoning in schools: a theoretical framework for evaluating inquiry tasks. Science Education, 86(2), 175-218.

Dede, Y. \& Yaman, S. (2008). Fen öğrenmeye yönelik motivasyon ölçeği: geçerlik ve güvenirlik çalışması [A questionnaire for motivation toward science learning: a validity and reliability study]. Necatibey Ĕgitim Fakültesi Elektronik Fen ve Matematik Eğitimi Dergisi, 2(1), 19-37.

de Jong, T. (2006). Computer simulations-technological advances in inquiry learning. Science, 312, 532-533.

Durmaz, H. \& Mutlu, S. (2014). The effects of an instructional intervention on 7th grade students' science process skills and science achievement. Çukurova Üniversitesi Ĕ̈itim Fakültesi Dergisi, 43(2), 155168.

Edelson, D. C., Gordin, D. N., \& Pea, R. D. (1999). Addressing the challenges of inquiry based learning through technology and curriculum design. Journal of the Learning Sciences, 8, 391-450.

Eslinger, E., White, B., Frederiksen, J., \& Brobst, J. (2008). Supporting inquiry process with an interactive learning environment: inquiry island. Journal of Science Education Technology, 17, 610-617.

Furtak, E. M., Seidel, T., Iverson, H., \& Briggs, D. C. (2012). Experimental and quasi experimental studies of inquiry-based science teaching: a meta-analysis. Review of Educational Research December, 82(3), 300-329.

Glesne, C. (2011). Becoming qualitative researchers. New York: Pearson.

Gündüz, H. B. (2010). Digital divide in Turkish primary schools: Sakarya sample. Turkish Online Journal of Education Technology, 9, 43-53.

Hofstein, A., Navon, O., Kipnis, M., \& Mamlok-Naaman, R. (2005). Developing students' ability to ask more and better questions resulting from inquiry-type chemistry laboratories. Journal of Research in Science Teaching, 42, 791-806.

Jarrett, D. (1997). Inquiry strategies for science and mathematics learning it's just good teaching. Oregon: Northwest Regional Educational Laboratory.

Johnson, A. P. (2014). Eylem araştırması el kitabı (Y. Uzuner, \& M. Özten Anay, Çev.). Ankara: Anı.

Kim, H. (2011). Inquiry-based science and technology enrichment program: Green earth enhanced with inquiry and technology. Journal of Science Education Technology, 20, 803-814.

Kim, M. C., \& Hannafin, M. J. (2011). Scaffolding 6th graders' problem solving in technology enhanced science classrooms: A qualitative case study. Instructional Science, 39, 255-282.

Koyunlu Ünlü., Z., \& Dökme, İ. (2011). The effect of combining anology-based simulation and laboratory activities on Turkish elementary school students' understanding of simple electric circuits. The Turkish Online Journal of Educational Technology, 10(4), 320-329.

Koyunlu Ünlü., Z., Dökme, İ., \& Sarıkaya, M. (2014). A comparison of the attitudes of rural and urban secondary school students towards the use of the internet. World Journal on Educational Technology, 6(2), 192-202.

Lazonder, A. W., \& Harmsen, R. (2016). Meta-analysis of inquiry-based learning: effects of guidance. Review of Educational Research, February 5, 1-38.

Lederman, J.S., \& Lederman, N.G. (2005). Nature of science is... Science and Children, 43(2), 53-54.

Lederman, J. S., Lederman, N. G., Bartos, S. A., Bartels, S. L., Meyer, A. A., \& Schwartz, R. S. (2014). Meaningful assessment of learners' understandings about scientific inquiry the views about scientific inquiry (VASI) questionnaire. Journal of Research in Science Teaching, 51(1), 65-83.

Lee, H-S., Linn, M. C., Varma, K., \& Liu, O. L. (2010). How do technology-enhanced inquiry science units impact classroom learning? Journal of Research in Science Teaching, 47(1), 71-90. 
Lee, H. S., \& Songer, N. B. (2003). Making authentic science accessible to students. International Journal of Science Education, 25(1), 1-26.

Li, Q. (2014). Student and teacher views about technology: a tale of two cities? Journal of Research on Technology in Education, 39(4), 377-397.

Lin, L. F., Hsu, Y-S., \& Yeh, Y-F. (2012). The role of computer simulation in an inquiry based learning environment: Reconstructing geological events as geologists. Journal of Science Educatıon Technology, 21, 370-383.

Lustick, D. (2009). The failure of inquiry: Preparing science teachers with an authentic investigation. Journal of Science Teacher Education, 20, 583-604.

Maeng, J. L., Mulvey, B. K., Smetana, L. K., \& Bell, R. L. (2013). Preservice teachers' TPACK: using technology to support inquiry instruction. Journal of Science Education and Technology, 22, 838-857.

Maeng, J. R. (2017). Using technology to facilitate differentiated high school science instruction. Research in Science Education, 47, 1075-1099.

Martin-Hansen, L. (2002). Defining inquiry. The Science Teacher, 69(2), 34-37.

MEB-TTKB. (2013). Ilköğretim kurumlarl (ilkokullar ve ortaokullar) fen bilimleri dersi (3, 4, 5, 6, 7 ve 8. sinıflar) öğretim programı [Foundational education institutions (3, 4, 5, 6, 7, and 8th grades) science curriculum]. Ankara: Talim ve Terbiye Kurulu Başkanlığı.

Melber, L. (2004). Inquiry for everyone: Authentic science experiences for students with special needs. Teaching Exceptional Children Plus, 1(2), Article 4.

Mills, G. E. (2007). Action research a guide for teacher researcher. Ohio: Pearson Merrill Hall.

National Research Council (NRC). (1996). Inquiry and national science education standarts. Washington, DC: National Academy.

National Research Council (NRC). (2000). Inquiry and national science education standarts. Washington, DC: National Academy.

Novak, A. M., \& Krajcik, J. S. (2006). Using technology to support inquiry in middle school science. In L. Flick, \& N. G. Lederman (Eds.), Scientific inquiry and nature of science (pp. 75-102). Norwell, MA: Kluwer Academic Publishers.

Ochsner, K. (2010). Lights, camera, action research: The effects of didactic digital movie making on students' twenty-first century learning skills and science content in the middle school classroom. Doctoral Dissertation, Arizona State University, Arizona.

Patton, M. Q. (2002). Qualitative research \& evaluation methods. California: Sage Publications.

Rendall, S. N. (1996). Information charts: A strategy for organizing student research. Journal of Adolescent and Adult Literacy, 39, 536-42.

Sadeh, I., \& Zion, M. (2012). Which type of inquiry project do high school biology students prefer: open or guided? Research Science Education, 42, 831-848.

Schwartz, R. S., Lederman, N. G., \& Lederman, J. S. (2008, March-April). An instrument to assess views of scientific inquiry: the VOSI questionnaire. Paper presented at the annual meeting of the National Association for Research in Science Teaching, Baltimore, MD.

Shahali, E. H. M., Halim, L., Treagust, D. F., Won, M., \& Chandrasegaran, A. L. (2017). Primary school teachers' understanding of science process skills in relation to their teaching qualifications and teaching experience. Research in Science Education, 47, 257-281.

Tan, M., \& Temiz, B. K. (2003). Fen öğretiminde bilimsel süreç becerilerinin yeri ve önemi [The importance and role of the science process skills in science teaching]. Pamukkale Üniversitesi Eğitim Fakültesi Dergisi, 1(13), 89-101.

Talanquer, V., Tomanek, D., \& Novodvorsky, I. (2013). Assessing students' understanding of inquiry: What do prospective science teachers notice? Journal of Research in Science Teaching, 50(2), 189-208.

Trundle, K. C., \& Hobson, S. (2011). To the moon and back: using technology to teach young children space science concepts. Science and Children, 49(4), 51-55.

TTK (Türk Telekomünikasyon Kurumu). (2002). Saylsal uçurum [Digital divide]. Sektörel Araştırma ve Stratejiler Dairesi Başkanlığ $1,1-5$.

Türkmen, H., \& Kandemir, M. (2011). Öğretmenlerin bilimsel süreç becerileri öğrenme alanı algıları üzerine bir durum çalışması [A case study on teachers' perceptions of scientific process skills]. Journal of European Education, 1(1), 15-24.

Uçar, S., \& Trundle, K. C. (2011). Conducting guided inquiry in science classes using authentic, archieved, web based data. Computers \& Education, 57, 1571-1582.

van Joolingen, W. R., de Jong, T., \& Dimitrakopoulout, A. (2006). Issues in computer supported inquiry learning in science. Journal of Computer Assisted Learning, 23, 111-119.

Waight, N., \& Abd-El-Khalick, F. (2007). The impact of technology on the enactment of "inquiry" in a technology enthusiast's sixth grade science classroom. Journal of Research in Science Teaching, 44(1), 154-182. 
Warner, A. J., \& Myers, B. E. (2011). Implementing inquiry-based teaching methods. University of Florida. Wilcoxon, F. (1945). Individual comparisons by ranking methods. Biometrics, 1, 80-83.

Yang, Y., Hu, X., Qu, Q., Lai, F., Shi, Y., Boswell, M., \& Rozelle, S. (2013). Roots of tomorrow's digital divide: computer use and internet access in China's elementary schools today. China \& World Economy, 21, 61-79.

\begin{tabular}{ll}
\hline & Author Information \\
\hline Zeynep Koyunlu Unlu & Ilbilge Dokme \\
Yozgat Bozok University & Gazi University \\
Department of Primary Education & Department of Mathematics and Science Education \\
Yozgat / Turkey & Ankara / Turkey \\
Contact e-mail: zeynepko.unlu@ gmail.com & \\
\hline
\end{tabular}

